\title{
Model Pembelajaran Snowball Throwing untuk Meningkatkan Kompetensi Siswa pada Materi Pengaruh Kalor
}

\author{
Sri Untari \\ SDN 1 Wonoharjo Kecamatan Wonogiri Kabupaten Wonogiri \\ E-mail: Sriuntari013@gmail.com*
}

Riwayat artikel: submit: 2 September 2021; revisi: 25 September 2021, diterima: 30 September 2021

\begin{abstract}
ABSTRAK
Tujuan penelitian ini adalah untuk meningkatkan kompetensi siswa dalam pengaruh kalor terhadap perubahan suhu dan wujud benda menggunakan model pembelajaran Snowball Throwing pada siswa kelas V SD Negeri 1 Wonoharjo. Jenis penelitian yang digunakan adalah Penelitian Tindakan Kelas (PTK). Dalam penelitian ini menggunakan dua siklus yaitu siklus I dan siklus II komponen perangkat terdiri dari perencanaan, tindakan pengamatan (observasi), dan refleksi. Subjek dalam penelitian ini adalah siswa kelas V SD Negeri 1 Wonoharjo yang berjumlah 5 orang. Sedangkan obyek penelitian adalah keseluruhan proses pada penerapan model Snowball Throwing di SD 1 Wonoharjo. Data hasil penelitian diperoleh dari hasil observasi, tes akhir siklus dan dokumentasi. Untuk analisis data deskriptif kuantitatif. Hasil penelitian menunjukkan penerapan model pembelajaran Snawball Throwing dapat meningkatkan proses pembelajaran pengaruh kalor terhadap perubahan suhu dan wujud benda terkait masalah kehidupan sehari - hari pada siswa kelas V semester II SDN 1 Wonoharjo tahun pelajaran 2019/2020 sebesar 40\% untuk antusias, 20\% untuk keaktifan, dan peran serta sebesar $40 \%$, ada peningkatan kompetensi pengaruh kalor terhadap perubahan suhu dan wujud benda sebesar $40 \%$, dan peningkatan perilaku/sikap sosial siswa sebesar $20 \%$ untuk disiplin siswa, $45 \%$ untuk sikap tanggung jawab, dan sikap percaya diri sebesar $25 \%$.
\end{abstract}

Kata kunci: Snowball Throwing, kompetensi, kalor

\section{ABSTRACT}

The purpose of this study is to improve students' competence in the influence of heat on changes in temperature and object form using the Snowball Throwing learning model in students of Grade $V$ of State Elementary School 1 Wonoharjo. The type of research used is Class Action Research (PTK). In this study using two cycles, cycle I and cycle II, the components of the device consisted of planning, observation, and reflection. The subjects in this study were students of class $V$ of State Elementary School 1 Wonoharjo which amounted to 5 people. While the object of the study is the whole process on the application of the Snowball Throwing model in SD 1 Wonoharjo. The data is obtained from observations, end-of-cycle tests and documentation. For quantitative descriptive data analysis. The results showed that the application of the Snawball Throwing learning model can increase the learning process of the influence of heat on changes in temperature and the form of objects related to problems of daily life in class V students of semester II SDN 1 Wonoharjo in the 2019/2020 school year by 40\% for enthusiasm, 20\% for activeness, and participation by 40\%, there is an increase in competence of kalor influence on changes in temperature and appearance of objects by $40 \%$, and an increase in student social behavior / attitude by $20 \%$ for student discipline, $45 \%$ for attitude of responsibility, and confidence by $25 \%$.

Keywords: Snowball Throwing,competence, calor 
Untari, S. (2021). Model Pembelajaran Snowball Throwing untuk Meningkatkan Kompetensi Siswa pada Materi Pengaruh Kalor. Edudikara: Jurnal Pendidikan dan Pembelajaran, 6(3), 187-198.

\section{PENDAHULUAN}

Pembelajaran merupakan hal penting dari sebuah proses pendidikan. Dimana dalam pembelajaran terdapat interaksi antara siswa dengan guru dalam kegiatan belajar mengajar. Pembelajaran merupakan suatu hal yang diberikan guru untuk membantu siswa memperoleh ilmu baik pengetahuan, sikap maupun keterampilan. Dengan harapan ilmu yang didapat tidak menyimpang dari tujuan pembelajaran. Pendidikan adalah usaha untuk mendapatkan pengetahuan, baik secara formal melalui sekolah maupun secara informal dari pendidikan di dalam rumah dan masyarakat ( Elfachmi dan Amien Kunaefi, 2016; Sridadi, 2020).

Proses pembelajaran merupakan inti dari kegiatan pendidikan di sekolah.Guru menjadi pengarah utama dalam menciptakan suasana belajar yang interaktif edukatif, yaitu interaksi antara guru dan siswa, siswa dengan siswa dan dengan sumber belajar yang menunjang tercapainya tujuan belajar. Proses belajar mengajar menuntut upaya guru untuk mengaktualisasikan kompetensinya secara professional, utamanya dalam aspek metodologis. (Kusumawati, 2017; Dewi, M. P., Putra, I. K. A., \& Negara, 2013). Fakta yang sering terjadi di lapangan, pembelajaran masih banyak secara konvensional hanya memberikan informasi tanpa adanya interaksi antara guru dan siswa. Pendidikan dan pengajaran dilakukan hanya sekedar pemberian informasi, pembelajaran tidak menarik, sehingga siswa kurang termotivasi dan merasa bosan, akhirnya berdampak pada rendahnya hasil belajar.

Proses pembelajaran pada kelas V SDN 1 Wonoharjo materi pengaruh kalor terhadap perubahan suhu dan wujud benda anak kurang antusias, pasif dan tidak tertarik. Guru dalam menjelaskan materi hanya menggunakan metode ceramah dan hanya melihat gambar di buku pelajaran. Guru menjelaskan materi pembelajaran dengan menggunakan metode ceramah, tidak semua siswa merespon dengan baik atau semangat. Mereka hanya mendengar tanpa mengetahui bentuk atau wujud dari hal yang mereka pelajari. Bagi siswa yang merasa bosan atau kurang tertarik dengan cara pengajaran guru, mereka hanya mendengarkan namun sulit memahami apa maksud dari materi yang disampaikan guru sehingga saat diberikan soal latihan mereka masih banyak bertanya tentang materi yang sudah disampaikan.

Pembelajaran yang monoton menyebabkan beberapa siswa mendapatkan nilai dibawah Kriteria Ketuntasan Minimal (KKM) Sekolah yang sudah ditetapkan yaitu 70. Jumlah siswa kelas V SDN 1 Wonoharjo Tahun Pelajaran 2019/2020 ada 5 siswa, terdiri dari 3 siswa laki-laki dan 2 siswa perempuan. Pembelajaran pada materi pengaruh kalor terhadap suhu dan wujud benda siswa yang aktif ada 3 siswa dan tidak aktif 2 siswa, antusias 2 siswa dan tidak antusias 3 siswa, peran serta ada 3 siswa dan 2 siswa kurang berperan serta. Tanggung jawab siswa saat melaksanakan tugas dari guru ada 3 siswa, 2 siswa kurang tanggung jawab. Siswa yang percaya diri dalam menyampaikan ulasan materi ada 2 dan 3 siswa percaya dirinya kurang.

Mengatasi permasalahan di SD Negeri 1 Wonoharjo terutama siswa kelas $V$ pada materi pengaruh kalor terhadap perubahan suhu dan wujud benda model pembelajaran Snowball Throwing. (Handayani, T., Mujasam, M., Widyaningsih, S. W., \& Yusuf, I, 2017). Model pembelajaran Snowball Throwing perlu dipersiapkan lembar pertanyaan yang berisi materi yang harus dikuasai dan dihafal masing-masing siswa. Salah satu siswa membentuk lembaran pertanyaan itu menyerupai bola, kemudian melempar bola ke temannya sambil bernyanyi selesai lagu siswa yang memegang bola menjawab pertanyaan dari lembar pertanyaan tersebut - lalu kegiatan pembelajaran diakhiri dengan mengevaluasi siswa dengan menanyakan pengetahuan yang mereka miliki dan pengetahuan yang mereka terima saat pembelajaran berlangsung. (Handayani, T., Mujasam, M., Widyaningsih, S. W., \& Yusuf, 2017; Sukirnadi, 2020) Model pembelajaran Snowball Throwing dipilih peneliti, karena melalui model ini, siswa belajar sambil bermain, dan dengan harapan siswa dapat menguasai materi dengan baik.

Pembelajaran model Snowball Throwing ini memiliki kelebihan di antaranya: 1) Meningkatkan jiwa kepemimpinan siswa, sebab ada ketua kelompok yang diberi tugas kepada teman-temannya. 2) Melatih siswa untuk belajar mandiri, karena masing-masing siswa diberikan 
Untari, S. (2021). Model Pembelajaran Snowball Throwing untuk Meningkatkan Kompetensi Siswa pada Materi Pengaruh Kalor. Edudikara: Jurnal Pendidikan dan Pembelajaran, 6(3), 187-198.

tugas untuk membuat satu pertanyaan, lalu pertanyaan itu akan dijawab oleh temannya atau sebaliknya. 3) Menumbuhkan kreativitas belajar siswa karena membuat bola sebagaimana yang diinginkannya. 4) Belajar lebih hidup, karena semua siswa aktif membuat pertanyaan ataupun menjawab soal temannya yang jatuh pada dirinya.(Huda,2014; Mahendra, 2018; Hujaemah, E., Saefurrohman, A., \& Juhji, 2019; Syahputra, 2020).

Pembelajaran dengan KI 2 Kompetensi sikap sosial dicapai saat proses pembelajaran berlangsung. Kompetensi sikap sosial pada pembelajaran ini aspek-aspek yang diamati adalah kerja sama, tanggung jawab dan percaya diri. Pembelajaran dengan Kompetensi Dasar 3.7. Menganalisis pengaruh kalor terhadap perubahan suhu dan wujud benda dalam kehidupan sehari-hari, semester 2 tahun pelajaran 2019/2020, dengan Kriteria Ketuntasan Minimal (KKM) 64. Hasil belajar dari 5 siswa pada KD 3,7 adalah 1 siswa mendapat nilai 80, 1 siswa mendapat nilai 70, 1 siswa mendapat nilai 60, 2 siswa mendapat nilai 30. Berdasarkan KKM yang telah ditetapkan 2 siswa dinyatakan tuntas dan 3 siswa belum tuntas. Nilai rata-rata dari 5 siswa tersebut adalah 54 dengan tingkat ketuntasan 40\%. Berdasarkan perolehan nilai tersebut terlihat ada kesenjangan nilai yang agak jauh, yaitu nilai tertinggi 80 dan nilai terendahnya 30 . Artinya siswa yang mendapat nilai 30 berarti tingkat penguasaan materinya masih jauh di bawah rata-rata.

\section{METODE}

Penelitian Tindakan Kelas ini diawali dengan persiapan berupa penyusunan proposal dan diakhiri dengan pembuatan laporan. Penelitian dilaksanakan selama 5 bulan dimulai pada bulan Januari 2020 dan diakhiri pada bulan Mei 2020, pada semester 2 tahun pelajaran 2019/2020. Penentuan tempat penelitian mempertimbangkan beberapa hal diantaranya : (a) Melaksanakan penelitian tidak meninggalkan tugas, (b) Pelaksanaan penelitian terhadap peningkatan kompetensi guru dalam proses pembelajaran.

Penelitian dilaksanakan di SD Negeri 1 Wonoharjo Kecamatan Wonogiri Kabupaten Wonogiri pada semester 2 tahun pelajaran 2019/2020. Penentuan tempat penelitian mempertimbangkan beberapa hal diantaranya : (a) Melaksanakan penelitian tidak meninggalkan tugas, (b) Pelaksanaan penelitian berpengaruh terhadap peningkatan kompetensi guru dalam proses pembelajaran di kelas masing-masing.

Berdasarkan masalah yang dikemukakan dalam penelitian ini, maka Subjek penelitian ini adalah peserta didik kelas V SDN 1 Wonoharjo Kecamatan Wonogiri Kabupaten Wonogiri Semester 2 Tahun Pelajaran 2019/2020 yang berjumlah 5 siswa .Objek penelitian yaitu kemampuan guru dalam pembelajaran menggunakan modeyang terdiri dari 2 siswa perempuan dan 3 siswa laki-laki.

Teknik dan Alat Pengumpulan Data dilakukan dengan beberapa teknik diantaranya : a)melalui dokumen yaitu mengumpulkan data hasil pengamatan guru pada saat pelaksanaan proses pembelajaran (kondisi awal) .b)Observasi yaitu mengumpulkan data dengan mengamati siswa saat pembelajaran pada setiap siklus.c)tes formatif untuk mengukur penguasaan materi d)melalui wawancara digunakan untuk mendapatkan data pendukung yang ditujukan kepada guru tentang masalah yang berkaitan dengan kondisi pembelajaran dan faktor-faktor yang mempengaruhi pembelajaran.d)melalui catatan lapangan adalah gambaran umum yang digunakan sebagai keperluan penjelasan dan penafsiran tetapi mencakup kesan dan penafsiran subjektif. Catatan tertulis berisi tentang apa yang didengar, dilihat, dialami, dan dipikirkan dalam rangka pengumpulan data dan refleksi terhadap data dalam penelitian. Waktu melakukan penelitian, peneliti mencatat berbagai hal yang dianggap penting untuk dijadikan sebagai data tambahan dalam penelitian guna mendukung analisis data.Alat pengumpulan data berupa instrument pedoman wawancara,lembar observasi,instrument tes dan pedoman dokumentasi.

Validasi sebagai bentuk validitas yaitu ketepatan (appropriateness), kebermaknaan (meaningfull) dan kemanfaatan (usefulness) dari sebuah kesimpulan yang didapatkan dari 
Untari, S. (2021). Model Pembelajaran Snowball Throwing untuk Meningkatkan Kompetensi Siswa pada Materi Pengaruh Kalor. Edudikara: Jurnal Pendidikan dan Pembelajaran, 6(3), 187-198.

interpretasi skor tes. Indikator kinerja /target telah ditentukan sebagai berikut:a) target yang ingin dicapai pada proses pembelajaran pada penelitian ini adalah dari pembelajaran yang kurang baik menjadi pembelajaran yang baik yaitu mencapai $80 \%$ masing-masing antusias, keaktifan, dan peran serta.Target penilaian ketuntasan klasikal mencapai $80 \%$.Indikator pelaksanaan proses pembelajaran sebagai berikut :tanggung jawab .kerjasama dan percaya diri mencapai $80 \%$ baik.

Desain penelitian ini menggunakan penelitian tindakan kelas /class action research. Penelitian tindakan kelas adalah suatu penelitian yang dilaksanakan secara sistematis reflektif terhadap berbagai tindakan yang dilakukan oleh guru yang sekaligus sebagai peneliti, sejak disusunnya suatu perencanaan sampai penilaian terhadap tindakan nyata di dalam kelas yang berupa kegiatan pembelajaran, untuk memperbaiki kondisi pembelajaran dan meningkatkan kualitas pembelajaran

\section{HASIL DAN PEMBAHASAN Hasil Penelitian}

\section{a. Proses pembelajaran}

Aktif mengikuti proses pembelajaran. Proses pembelajaran pengaruh kalor terhadap perubahan suhu dan wujud benda pada prasiklus menggunakan metode mengajar tanya jawab. Siswa yang aktif dalam pembelajaran sebanyak 2 siswa, sedangkan 3 siswa lainnya belum aktif. Tingkat keaktifan siswa mencapai $40 \%$ dengan kategori kurang.Proses pembelajaran pengaruh kalor terhadap perubahan suhu dan wujud benda pada siklus I menggunakan model pembelajaran snowball throwing dengan media pembelajaran lembar kertas pertanyaan. Siswa yang aktif mengikuti pembelajaran sebanyak 3 siswa, sedangkan 2 siswa belum aktif.Tingkat keaktifan siswa mencapai $60 \%$ dengan kategori cukup.Proses pembelajaran pengaruh kalor terhadap perubahan suhu dan wujud benda pada siklus II menggunakan model pembelajaran snowball throwing dengan media pembelajaran lembar kertas pertanyaan. Siswa yang aktif mengikuti pembelajaran sebanyak 4 siswa, sedangkan 1 siswa belum aktif. Tingkat keaktifan siswa mencapai 80 \% dengan kategori baik. Data keaktifan siswa pada Prasiklus, Siklus I, dan Siklus II dirinci sesuai indikator proses pembelajaran sebagai berikut :

Tabel 1. Data Keaktifan Siswa

\begin{tabular}{ccccc}
\hline No. & & Prasiklus & Siklus I & Siklus II \\
\hline 1. & Jumlah Siswa & 2 & 3 & 4 \\
2. & Persentase & $40 \%$ & $60 \%$ & $80 \%$ \\
\hline
\end{tabular}

Antusias dalam proses pembelajaran. Proses pembelajaran pengaruh kalor terhadap perubahan suhu dan wujud benda pada prasiklus, siswa yang antusias dalam pembelajaran sebanyak 2 anak, sedangkan 3 siswa lainnya belum antusias. Tingkat antusias siswa mencapai $40 \%$ kategori kurang.Proses pembelajaran pengaruh kalor terhadap perubahan suhu dan wujud benda pada siklus I, siswa yang antusias mengikuti pembelajaran sebanyak 3 siswa, sedangkan 2 siswa belum antusias. Tingkat antusias siswa mencapai $60 \%$ dengan kategori cukup.Proses pembelajaran pengaruh kalor terhadap perubahan suhu dan wujud benda pada siklus II, siswa yang antusias mengikuti pembelajaran sebanyak 4 siswa, sedangkan 1 siswa belum antusias. Tingkat antusias siswa mencapai $80 \%$ dengan kategori baik. Data antusias siswa Prasiklus, Siklus I, dan Siklus II dirinci sesuai indikator proses pembelajaran sebagai berikut : 
Untari, S. (2021). Model Pembelajaran Snowball Throwing untuk Meningkatkan Kompetensi Siswa pada Materi Pengaruh Kalor. Edudikara: Jurnal Pendidikan dan Pembelajaran, 6(3), 187-198.

Tabel 2. Data Antusias Siswa

\begin{tabular}{clccc}
\hline No & & Prasiklus & Siklus I & Siklus II \\
\hline 1 & Jumlah Siswa & 2 & 3 & 4 \\
2 & Persentase & $40 \%$ & $60 \%$ & $80 \%$ \\
\hline
\end{tabular}

Peran serta dalam proses pembelajaran. Proses pembelajaran pengaruh kalor terhadap perubahan suhu dan wujud benda pada prasiklus, siswa yang berperan serta dengan baik dalam pembelajaran sebanyak 3 siswa, sedangkan 2 siswa lainnya belum berperan serta dengan baik. Tingkat peran serta siswa mencapai $60 \%$ dengan kategori cukup.Proses pembelajaran pengaruh kalor terhadap perubahan suhu dan wujud benda pada siklus I, semua siswa berperan serta dengan baik dalam pembelajaran dengan model snowball throwing. Tingkat peran serta siswa mencapai $80 \%$ dengan kategori baik. Proses pembelajaran pengaruh kalor terhadap perubahan suhu dan wujud benda pada siklus II dengan model pembelajaran snowball throwing semua siswa berperan serta dengan baik dalam pembelajaran karena semua siswa harus mencari pasangan masing-masing. Tingkat peran serta siswa mencapai $100 \%$ dengan kategori amat baik.Data peran serta siswa Prasiklus, Siklus I, dan Siklus II dirinci sesuai indikator proses pembelajaran sebagai berikut :

Tabel 3. Data Peran Serta Siswa

\begin{tabular}{ccccc}
\hline No. & Uraian & Prasiklus & Siklus I & Siklus II \\
\hline 1. & Jumlah Siswa & 3 & 4 & 5 \\
2. & Persentase & $60 \%$ & $80 \%$ & $100 \%$ \\
3 & Kategori & Cukup & Baik & Amat Baik \\
\hline
\end{tabular}

\section{b. Kompetensi Pengetahuan (KI 3)}

Hasil belajar KI 3 KD 3.7. Menganalisis pengaruh kalor terhadap perubahan suhu dan wujud benda dalam kehidupan sehari-hari, sebagai berikut :

Tabel 4. Hasil Kompetensi KI 3 KD 3.7 Persiklus

\begin{tabular}{clccc}
\hline No. & & Prasiklus & Siklus I & Siklus II \\
\hline 1. & Siswa tuntas & 2 & 3 & 4 \\
2. & Persentase & $40 \%$ & $60 \%$ & $80 \%$ \\
3. & Rata-rata & 54 & 78 & 80 \\
\hline
\end{tabular}

\section{c. Perilaku Siswa (KI 2)}

Kerja sama dalam kegiatan pembelajaran. Kegiatan pembelajaran pengaruh kalor terhadap perubahan suhu dan wujud benda pada prasiklus menggunakan metode mengajar tanya jawab. Siswa yang menunjukkan kerja sama yang baik dalam pembelajaran sebanyak 2 siswa, sedangkan 3 siswa lainnya belum menunjukkan kerja sama yang baik. Tingkat kerja sama siswa mencapai $40 \%$ dengan kategori kurang.

Kegiatan pembelajaran pengaruh kalor terhadap perubahan suhu dan wujud benda pada siklus I menggunakan model pembelajaran snowball throwing dengan media pembelajaran lembar kertas pertanyaan. Siswa yang kerja sama dengan baik sebanyak 3 siswa, sedangkan 2 siswa belum menunjukkan kerja sama yang baik. Tingkat kerja sama siswa mencapai $60 \%$ dengan kategori cukup. 
Untari, S. (2021). Model Pembelajaran Snowball Throwing untuk Meningkatkan Kompetensi Siswa pada Materi Pengaruh Kalor. Edudikara: Jurnal Pendidikan dan Pembelajaran, 6(3), 187-198.

Kegiatan pembelajaran pengaruh kalor terhadap perubahan suhu dan wujud benda pada siklus II menggunakan model pembelajaran snowball throwing dengan media pembelajaran lembar kertas pertanyaan. Siswa yang kerja sama dalam pembelajaran sebanyak 4 siswa, sedangkan 1siswa belum bisa diajak kerja sama dengan baik. Tingkat kerja sama siswa mencapai $80 \%$ dengan kategori baik. Data tingkat kerja sama siswa pada Prasiklus, Siklus I, dan Siklus II dirinci sesuai indikator proses pembelajaran sebagai berikut :

Tabel 5. Data Kerja sama Siswa

\begin{tabular}{ccccc}
\hline No. & Uraian & Prasiklus & Siklus I & Siklus II \\
\hline 1. & Jumlah Siswa & 2 & 3 & 4 \\
2. & Persentase & $40 \%$ & $60 \%$ & $80 \%$ \\
\hline
\end{tabular}

1) Tanggung jawab dalam kegiatan pembelajaran

Kegiatan pembelajaran pengaruh kalor terhadap perubahan suhu dan wujud benda pada prasiklus, siswa yang tanggung jawab dalam pembelajaran sebanyak 2 anak, sedangkan 3 siswa lainnya belum antusias. Tingkat antusias siswa mencapai $40 \%$ (kurang).Kegiatan pembelajaran pengaruh kalor terhadap perubahan suhu dan wujud benda pada siklus I, siswa yang tanggung jawab mengikuti pembelajaran sebanyak 3 siswa, sedangkan 5 siswa belum tanggung jawab. Tingkat antusias siswa mencapai $60 \%$ (cukup).Kegiatan pembelajaran pengaruh kalor terhadap perubahan suhu dan wujud benda pada siklus II, siswa yang tanggung jawab mengikuti pembelajaran sebanyak 5 siswa, sedangkan 0 siswa belum tanggung jawab. Tingkat antusias siswa mencapai 100 $\%$ (amat baik)

Data tanggung jawab siswa Prasiklus, Siklus I, dan Siklus II dirinci sesuai indikator proses pembelajaran sebagai berikut :

Tabel 6. Data Tanggung jawab Siswa

\begin{tabular}{clccc}
\hline No & Uraian & Prasiklus & Siklus I & Siklus II \\
\hline 1 & Jumlah Siswa & 2 & 3 & 5 \\
2 & Persentase & $40 \%$ & $60 \%$ & $100 \%$ \\
3 & Kategori & Kurang & Cukup & Amat Baik \\
\hline
\end{tabular}

2) Percaya diri dalam kegiatan pembelajaran

Kegiatan pembelajaran pengaruh kalor terhadap perubahan suhu dan wujud benda pada prasiklus, siswa yang percaya diri dalam kegiatan pembelajaran sebanyak 3 siswa, sedangkan 2 siswa lainnya belum percaya diri . Tingkat percaya diri siswa mencapai $60 \%$ dengan kategori cukup.

Kegiatan pembelajaran pengaruh kalor terhadap perubahan suhu dan wujud benda pada siklus I dengan model pembelajaran snowball throwing, 3 siswa percaya diri dan 2 siswa belum percaya diri. Tingkat percaya diri siswa masih sama $60 \%$ kategori cukup.

Kegiatan pembelajaran pengaruh kalor terhadap perubahan suhu dan wujud benda pada siklus II dengan model pembelajaran snowball throwing 4 siswa percaya diri, 1 siswa masih kurang percaya diri. Tingkat percaya diri siswa mencapai 80 \% (baik).Data percaya diri siswa Prasiklus, Siklus I, dan Siklus II dirinci sesuai indikator proses pembelajaran sebagai berikut : 
Untari, S. (2021). Model Pembelajaran Snowball Throwing untuk Meningkatkan Kompetensi Siswa pada Materi Pengaruh Kalor. Edudikara: Jurnal Pendidikan dan Pembelajaran, 6(3), 187-198.

Tabel 7. Data Percaya diri Siswa

\begin{tabular}{clccc}
\hline No. & & Prasiklus & Siklus I & Siklus II \\
\hline 1. & Jumlah Siswa & 3 & 3 & 4 \\
2. & Persentase & $60 \%$ & $60 \%$ & $80 \%$ \\
3 & Kategori & Cukup & Cukup & Baik \\
\hline
\end{tabular}

\section{Pembahasan}

\section{Proses pembelajaran}

Aktif mengikuti proses pembelajaran. Berdasarkan data keaktifan siswa, terjadi peningkatan keaktifan siswa dalam mengikuti proses pembelajaran pengaruh kalor terhadap perubahan suhu dan wujud benda sebesar $20 \%$ dari $40 \%$ pada prasiklus menjadi $60 \%$ pada siklus I, dan kenaikan sebesar $20 \%$ dari $60 \%$ pada siklus I menjadi $80 \%$ pada siklus II.

Peningkatan keaktifan proses pembelajaran dapat dilihat pada grafik berikut ini :

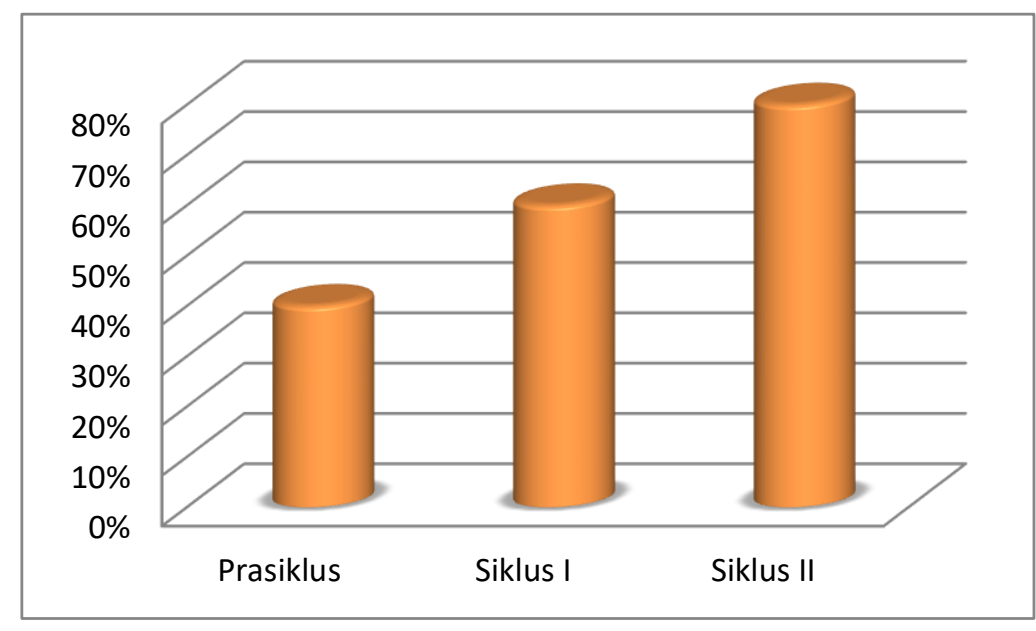

Gambar 1. Grafik Peningkatan Keaktifan Siswa

Antusias dalam proses pembelajaran. Peningkatan antusias siswa dalam mengikuti proses pembelajaran pengaruh kalor terhadap perubahan suhu dan wujud benda sebesar $20 \%$ dari 40 $\%$ pada prasiklus menjadi $60 \%$ pada siklus I, dan kenaikan sebesar $20 \%$ dari $60 \%$ pada siklus I menjadi $80 \%$ pada siklus II dapat dilihat pada grafik berikut ini :

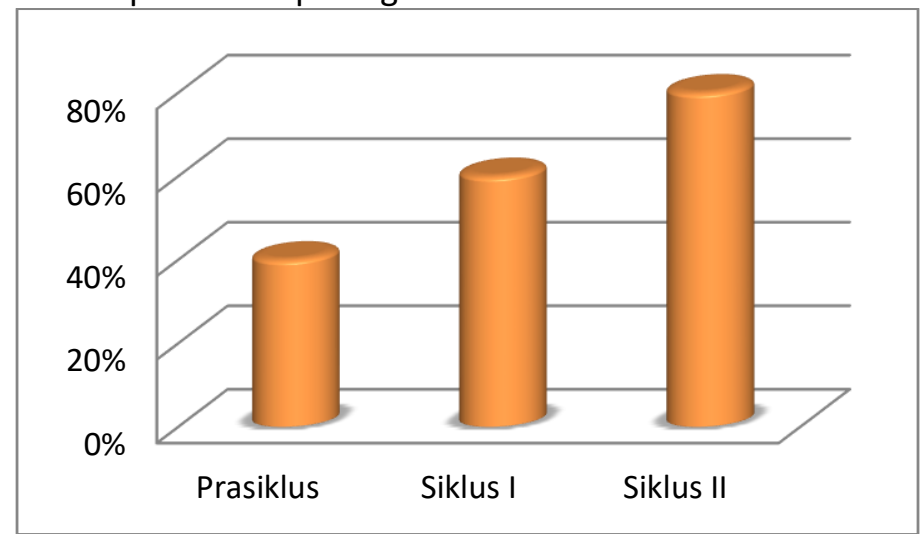

Gambar 2. Peningkatan Antusias Siswa 
Untari, S. (2021). Model Pembelajaran Snowball Throwing untuk Meningkatkan Kompetensi Siswa pada Materi Pengaruh Kalor. Edudikara: Jurnal Pendidikan dan Pembelajaran, 6(3), 187-198.

Peran serta dalam proses pembelajaran. Berdasarkan analisis data terjadi peningkatan peran serta siswa dalam mengikuti proses pembelajaran pengaruh kalor terhadap perubahan suhu dan wujud benda sebesar $20 \%$ dari $60 \%$ pada prasiklus menjadi $80 \%$ pada siklus I, dan kenaikan sebesar $20 \%$ dari $80 \%$ pada siklus I menjadi $100 \%$ pada siklus II.

Peningkatan peran serta dalam proses pembelajaran dan kenaikan sebesar $20 \%$ dari $60 \%$ pada siklus I menjadi $80 \%$ pada siklus II menjadi $100 \%$ dapat dilihat pada grafik berikut ini :

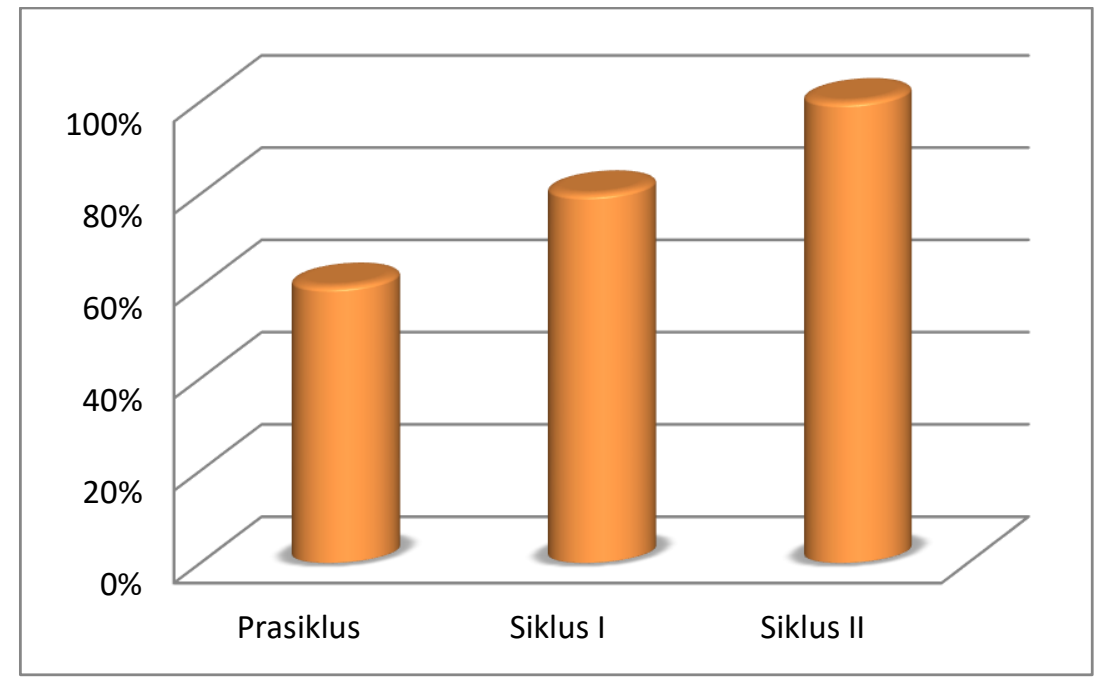

Gambar 3. Peningkatan Peran Serta Siswa

Data proses pembelajaran siswa secara keseluruhan dari prasiklus, siklus I, dan siklus II dirinci sesuai indikator proses pembelajaran sebagai berikut :

Tabel 8. Hasil Proses Pembelajaran Tiap Siklus

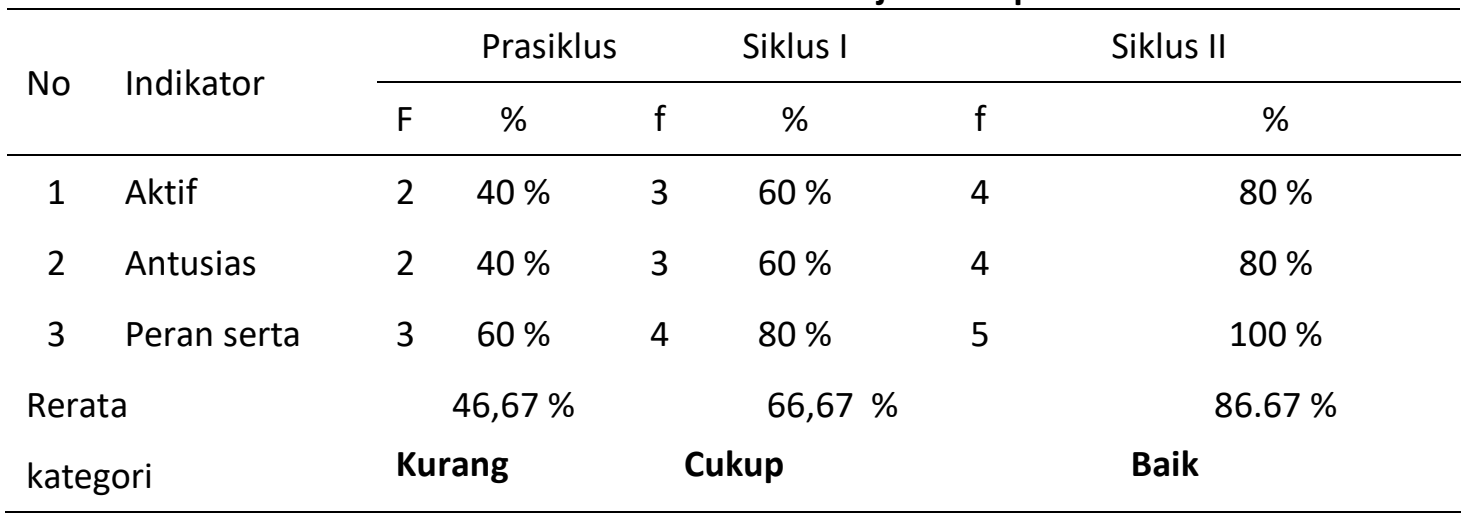

Berdasarkan data dari tabel di atas, maka proses pembelajaran dan kenaikan sebesar $20 \%$ dari $60 \%$ pada siklus I menjadi $80 \%$ pada siklus II pada prasiklus tingkat keaktifan siswa sebesar $40 \%$, antusias siswa $40 \%$, dan peran serta siswa $60 \%$. Rata-rata yang dicapai dalam proses pembelajaran $46,67 \%$ dengan kategori kurang

Proses dan kenaikan sebesar $20 \%$ dari $60 \%$ pada siklus I menjadi $80 \%$ pada siklus II pada siklus I tingkat keaktifan siswa sebesar $60 \%$, antusias siswa $60 \%$, dan peran serta siswa $80 \%$. Rata-rata yang dicapai dalam proses pembelajaran $66,67 \%$ dengan kategori cukup.

Proses pembelajaran dan kenaikan sebesar $20 \%$ dari $80 \%$ pada siklus I menjadi $100 \%$ pada siklus II pada siklus II tingkat keaktifan siswa sebesar $80 \%$, antusias siswa $80 \%$, dan peran serta 
Untari, S. (2021). Model Pembelajaran Snowball Throwing untuk Meningkatkan Kompetensi Siswa pada Materi Pengaruh Kalor. Edudikara: Jurnal Pendidikan dan Pembelajaran, 6(3), 187-198.

siswa $100 \%$. Rata-rata yang dicapai dalam proses pembelajaran $86,67 \%$ dengan kategori baik. Berdasarkan uraian di atas, terjadi peningkatan rata-rata pada proses pembelajaran pengaruh kalor terhadap perubahan suhu dan wujud benda sebesar $20 \%$ dari 46,67 \% pada prasiklus menjadi $66,67 \%$ pada siklus I, dan $86,67 \%$ pada siklus II.

Peningkatan rata-rata proses pembelajaran pengaruh kalor terhadap perubahan suhu dan wujud benda dapat dilihat pada grafik berikut :

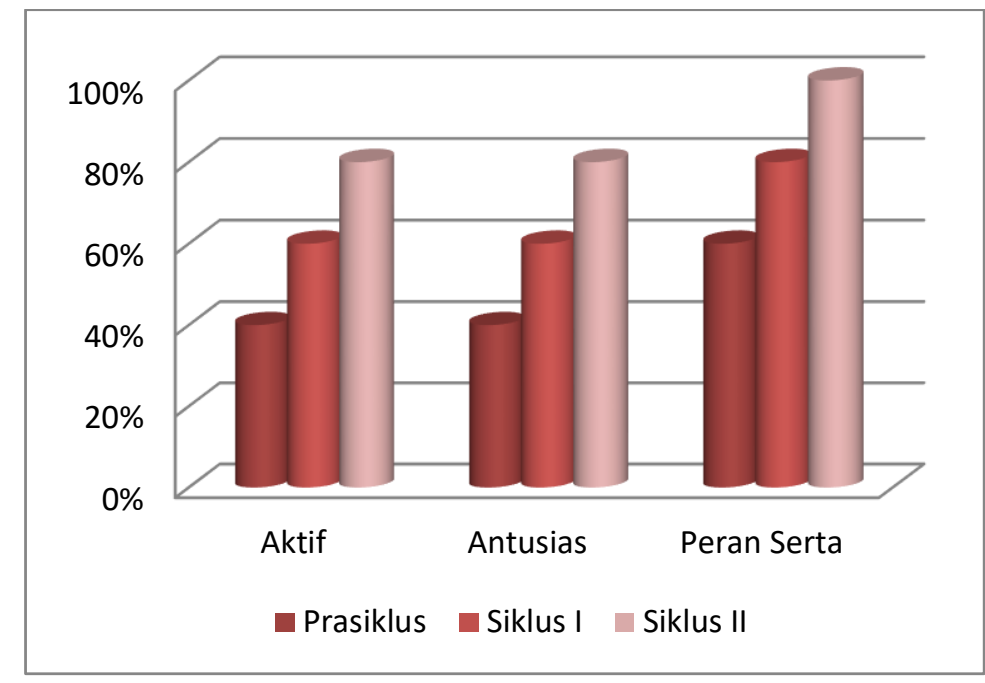

Gambar 4. Peningkatan Rata-rata Proses Pembelajaran

\section{a. Kompetensi Pengetahuan (KI 3)}

Pada KI 3 terjadi peningkatan 24 dari 54 pada rata-rata prasiklus menjadi 78 pada siklus I, dan peningkatan 2 dari 78 rata-rata siklus I menjadi 80 pada siklus II.Peningkatan nilai rata-rata Kompetensi KI 3 pada KD 3.7 Menganalisis pengaruh kalor terhadap perubahan suhu dan wujud benda dalam kehidupan sehari-hari dapat dilihat pada grafik di bawah ini :

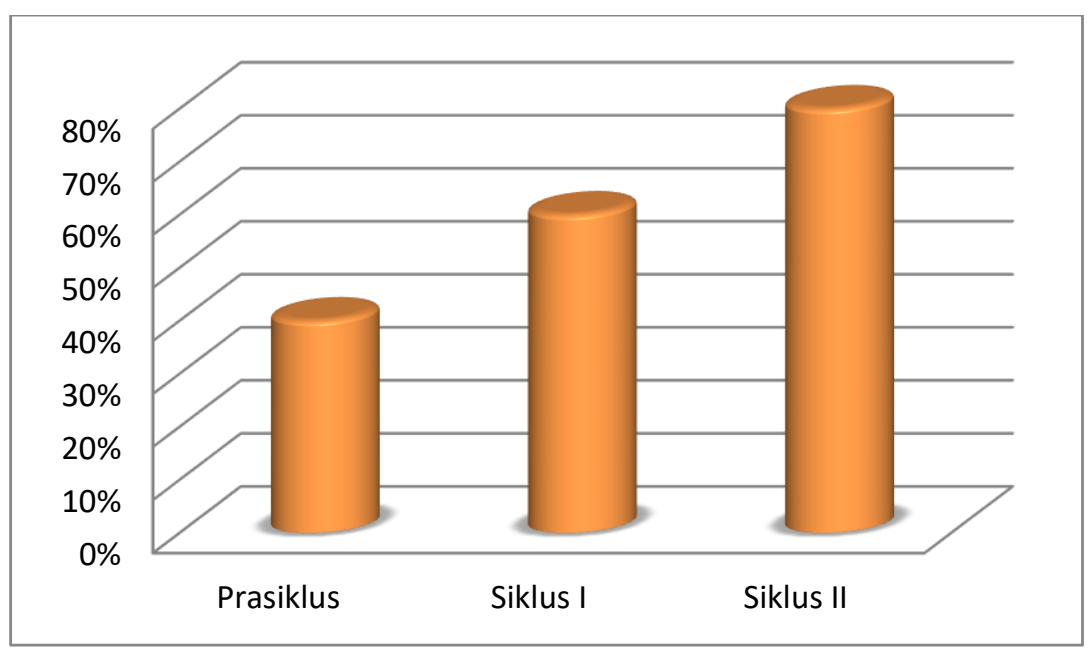

Gambar 5. Peningkatan Nilai Rata-rata Kelas KI 3 
Untari, S. (2021). Model Pembelajaran Snowball Throwing untuk Meningkatkan Kompetensi Siswa pada Materi Pengaruh Kalor. Edudikara: Jurnal Pendidikan dan Pembelajaran, 6(3), 187-198.

\section{b. Perilaku Siswa (KI 2)}

Tabel 9. Hasil Perilaku Siswa Persiklus

\begin{tabular}{|c|c|c|c|c|c|c|c|}
\hline \multirow{2}{*}{ No } & \multirow{2}{*}{ Indikator } & \multicolumn{2}{|c|}{ Prasiklus } & \multicolumn{2}{|c|}{ Siklus I } & \multicolumn{2}{|c|}{ Siklus II } \\
\hline & & $f$ & $\%$ & $f$ & $\%$ & $f$ & $\%$ \\
\hline 1 & Kerja sama & 2 & $40 \%$ & 3 & $60 \%$ & 4 & $80 \%$ \\
\hline 2 & Tanggung jawab & 2 & $40 \%$ & 3 & $60 \%$ & 5 & $100 \%$ \\
\hline 3 & Percaya diri & 3 & $60 \%$ & 3 & $60 \%$ & 4 & $80 \%$ \\
\hline \multicolumn{2}{|c|}{ Rerata } & \multicolumn{2}{|c|}{$46,67 \%$} & \multicolumn{2}{|r|}{$60 \%$} & \multicolumn{2}{|r|}{$86,67 \%$} \\
\hline \multicolumn{2}{|c|}{ Kategori } & \multicolumn{2}{|c|}{ Kurang } & \multicolumn{2}{|c|}{ Cukup } & \multicolumn{2}{|c|}{ Baik } \\
\hline
\end{tabular}

Berdasarkan data dari tabel di atas, maka peningkatan perilaku siswa dalam pembelajaran pengaruh kalor terhadap perubahan suhu dan wujud benda pada prasiklus tingkat kerja sama siswa sebesar $20 \%$, tanggung jawab siswa $40 \%$, dan percaya diri siswa $60 \%$. Rata-rata yang dicapai dalam perilaku siswa dalam pembelajaran $46,67 \%$ dengan kategori kurang.

Proses pembelajaran pengaruh kalor terhadap perubahan suhu dan wujud benda pada siklus I tingkat kerja sama siswa sebesar $60 \%$, tanggung jawab siswa $60 \%$, dan percaya diri siswa $60 \%$. Rata-rata yang dicapai dalam proses pembelajaran $60 \%$ dengan kategori cukup.

Pada siklus II tingkat kerja sama siswa sebesar $80 \%$, tanggung jawab siswa $100 \%$, dan percaya diri siswa $80 \%$. Rata-rata yang dicapai dalam proses pembelajaran $86,67 \%$ dengan kategori baik.

Berdasarkan uraian di atas, terjadi peningkatan rata-rata perilaku siswa dalam pembelajaran pengaruh kalor terhadap perubahan suhu dan wujud benda sebesar $13.33 \%$ dari $46,67 \%$ pada prasiklus menjadi $60 \%$ pada siklus I, dan peningkatan $26,67 \%$ dari $60 \%$ pada siklus I menjadi $86,67 \%$ pada siklus II. Peningkatan rata-rata perilaku siswa dalam pembelajaran pengaruh kalor terhadap perubahan suhu dan wujud benda dapa dilihat pada grafik berikut :

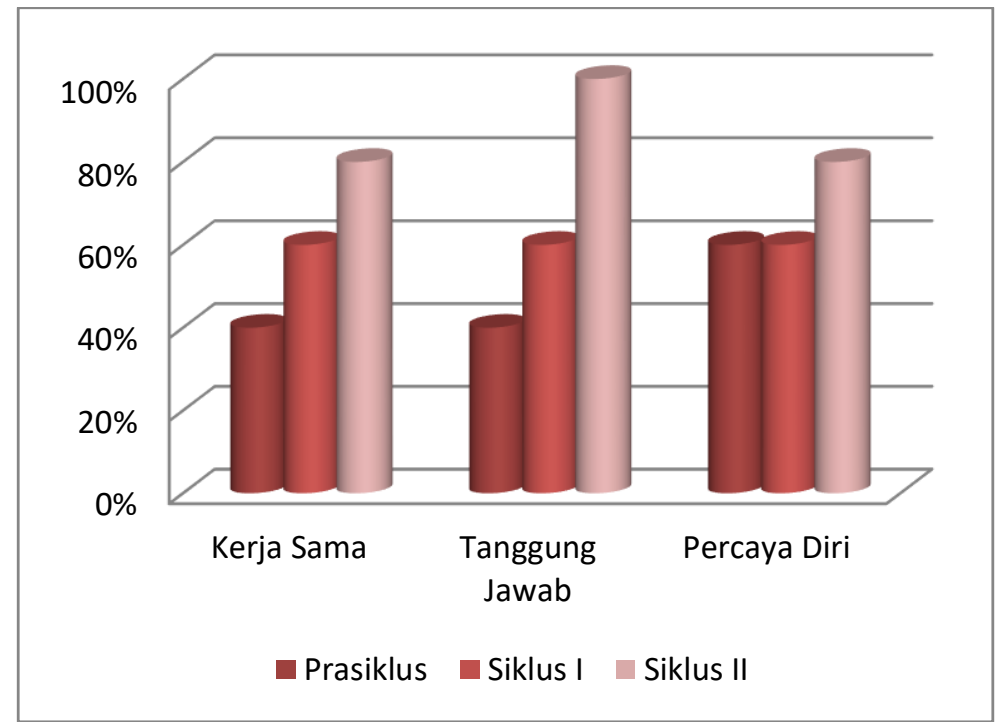

Gambar 6. Peningkatan Rata-rata Perilaku Siswa

Berdasarkan uraian di atas dapat disimpulkan bahwa terdapat peningkatan tiap indikator kinerja siswa baik pada proses pembelajaran maupun pada hasil belajar KI 3 dan perilaku atau sikap sosial siswa (KI 2) dengan menggunakan model pembelajaran snowball throwing dalam pembelajaran materi pengaruh kalor terhadap perubahan suhu dan wujud benda.Data menunjukkan pelaksanaan Siklus II telah mencapai target indikator kinerja yaitu proses 
Untari, S. (2021). Model Pembelajaran Snowball Throwing untuk Meningkatkan Kompetensi Siswa pada Materi Pengaruh Kalor. Edudikara: Jurnal Pendidikan dan Pembelajaran, 6(3), 187-198.

pembelajaran minimal masuk dalam kategori baik dan ketuntasan klasikal hasil belajar KI 3 mencapai $80 \%$.

Kenaikan rata-rata secara keseluruhan dari indikator kinerja tersebut menunjukkan kelebihan penggunaan model pembelajaran snowball throwing. Terjadinya kenaikan rata-rata menunjukan jumlah siswa yang memahami materi mengalami peningkatan tiap siklusnya. Terlampauinya semua indikator kinerja menunjukan keberhasilan tindakan penelitian ini, oleh karena itu penelitian dihentikan sampai siklus II ini.

\section{SIMPULAN DAN SARAN}

Berdasarkan hasil penelitian dan pembahasan sebagaimana diuraikan pada bab IV, kesimpulan penelitian ini adalah sebagai berikut: Hasil penelitian menunjukkan penerapan model pembelajaran Snawball Throwing dapat meningkatkan proses pembelajaran pengaruh kalor terhadap perubahan suhu dan wujud benda terkait masalah kehidupan sehari - hari pada siswa kelas V semester II SDN 1 Wonoharjo tahun pelajaran 2019/2020 sebesar 40\% untuk antusias, $20 \%$ untuk keaktifan, dan peran serta sebesar $40 \%$. Terdapat peningkatan kompetensi pengaruh kalor terhadap perubahan suhu dan wujud benda pada siswa kelas $V$ semester 2 SDN 1 Wonoharjo tahun pelajaran 2019/2020 sebesar 40\%. Peningkatan perilaku/sikap sosial siswa setelah diberikan model pembelajaran Snowball Throwing pada siswa kelas V semester 2 SDN 1 Wonoharjo tahun pelajaran 2019/2020 sebesar 20\% untuk disiplin siswa, 45\% untuk sikap tanggung jawab, dan sikap percaya diri sebesar $25 \%$.

Berdasarkan kesimpulan di atas maka dapat direkomendasikan pada guru diharapkan dapat mengembangkan model pembelajaran yang dapat mendorong motivasi siswa dan mempermudah siswa dalam memahami pembelajaran IPA maupun mapel yang lain dan mampu dapat meningkatkan kemampuannya dalam mengembangkan dan menyampaikan materi, serta mengelola kelas. Sedangkan Siswa hendaknya fokus dengan baik saat penerapan model pembelajaran Snawball Throwing maupun saat kegiatan pembelajaran berlangsung. Selain itu, pihak sekolah hendaknya membuat kebijakan kepada guru untuk melakukan penelitian tindakan kelas dalam rangka perbaikan proses pembelajaran dan meningkatan kualitas pembelajaran.

\section{REFERENSI}

Agus Suprijono. (2012). Cooperative Learning. Yogyakarta: CV. Pustaka Belajar.

Asep Jihad dan Abdul Haris. (2013). Evaluasi Pembelajaran. Yogyakarta: CV Multi Pressindo.

Dewi, M. P., Putra, I. K. A., \& Negara, I. G. A. O. (2013). Pengaruh Model Pembelajaran Snowball Throwing terhadap Hasil Belajar IPA Siswa Kelas V SD di Gugus Sri Kandi Kecamatan Denpasar Timur. Mimbar PGSD Undiksha, 1(1).

Handayani, T., Mujasam, M., Widyaningsih, S. W., \& Yusuf, I. (2017). Penerapan model pembelajaran kooperatif tipe Snowball throwing terhadap hasil belajar Peserta didik. Curricula: Journal of Teaching and Learning, 2(1).

Hamdani. (2010). Strategi Belajar Mengajar. Bandung: CV. Pustaka Setia.

Hisbullah, H., \& Firman, F. (2019). Penerapan Model Pembelajaran Snowball Throwing dalam Meningkatkan Hasil Belajar Ilmu Pengetahuan Alam di Sekolah Dasar. Cokroaminoto Journal of Primary Education, 2(2), 100-113.

Hujaemah, E., Saefurrohman, A., \& Juhji, J. (2019). Pengaruh Penerapan Model Snowball Throwing Terhadap Hasil Belajar IPA Di Sekolah Dasar. Muallimuna: Jurnal Madrasah Ibtidaiyah, 5(1), 23-32.

Kokom Komalasari. (2010). Pembelajaran Kontektual. Bandung: PT Refika Aditama.

Kusumawati, N. (2017). Pengaruh Model Pembelajaran Kooperatif Dengan Snowball Throwing Terhadap Hasil Belajar IPA pada siswa kelas IV SDN Bondrang Kecamatan Sawoo Kabupaten Ponorogo. Ibriez: Jurnal Kependidikan Dasar Islam Berbasis Sains, 2(1), 1-12.

Mahendra, M. (2018). Penggunaan Snowball Throwing Untuk Menngkatkan Motivasi Dan Hasil Belajar Ilmu Pengetahuan Sosial. Jurnal Dikdas Bantara, 1(1).

Miftahul Huda. (2013). Model-model Pengajaran dan Pembelajaran. Yogyakarta: CV. Pustaka Pelajar. Modul PLPG. (2013). Pedagogi Khusus Sekolah Dasar. Badan Penerbit FKIP-UMS. 
Untari, S. (2021). Model Pembelajaran Snowball Throwing untuk Meningkatkan Kompetensi Siswa pada Materi Pengaruh Kalor. Edudikara: Jurnal Pendidikan dan Pembelajaran, 6(3), 187-198.

Moh Sholeh Hamid. (2011). Metode Edutainment. Yogyakarta: Diva Press.

Rudi Susilana, Cepi Riyana. (2012). Media Pembelajaran. Bandung: CV. Wacana Prima.

Sridadi, S. (2020). Peningkatan Hasil Belajar IPA Melalui Model Pembelajaran Kooperatif Team Game Tournament Pada Siswa Kelas VIII SMP. Edudikara: Jurnal Pendidikan dan Pembelajaran, 5(3), 183194.

Sukirnadi, S. (2020). Peningkatan Prestasi Belajar Ipa Menggunakan Metode Demonstrasi Pada Siswa Kelas VIII SMP. Edudikara: Jurnal Pendidikan dan Pembelajaran, 5(3), 210-221.

Suyono, Hariyanto. (2011). Belajar dan Pembelajaran. Bandung: PT. Remaja Rosdakarya.

Syahputra, E. (2020). Snowball throwing tingkatkan minat dan hasil belajar. Haura Publishing.

Tim. (2017). Buku Tematik Terpadu Kurikulum 2017 Tema 7. Peristiwa dalam Kehidupan. Jakarta: Kementerian Pendidikan dan Kebudayaan

Trianto. (2010). Model Pembelajaran Terpadu. Jakarta:Bumi Aksara 